Available online on 15.11.2017 at http://ujpr.org
Universal Journal of Pharmaceutical Research
An International Peer Reviewed Journal
Open access to Pharmaceutical research

\title{
SERO-PREVALENCE OF HEPATITIS C VIRUS AMONG DENTAL CLINIC WORKERS IN SANA'A CITY - YEMEN AND THE RISK FACTORS CONTRIBUTING FOR ITS INFECTION
}

Abbas M Al-Kebsi' ${ }^{1}$, Arwa M Othman' ${ }^{(D,}$, Al-Kasem M A Abbas ${ }^{3}$, Ebtihal M Madar ${ }^{2}$, Hassan A. Al-Shamahy ${ }^{2}$, Khaled M Al-Gaffari ${ }^{1}$ (D), Samera M. Naser Daname ${ }^{4}$, , Fuad L. Motareb $^{5}$ (D) ${ }^{I}$ Department of Prosthodontics, Faculty of Dentistry, Sana' a University, Republic of Yemen.

${ }^{2}$ Medical Microbiology and Clinical Immunology, Faculty of Medicine and Health Sciences, Sana' a University, Yemen.

${ }^{3}$ Department of Maxillo-Facial, Faculty of Dentistry, Sana'a University, Republic of Yemen.

${ }^{4}$ Department of Physiology, Faculty of Dentistry, Sana' a University, Republic of Yemen.

${ }^{5}$ Department of Orthodontics, Faculty of Dentistry, Sana' a University, Republic of Yemen.

\section{ABSTRACT}

Objectives: Dental clinic workers (DCWs) in Yemen have an additional risk of getting infected with HCV from their work place and till now there is no study in prevalence of HCV infection and associated risk factors among DCWs. The purposes of this survey were to evaluate what proportion of dentists and dental assistants had serological evidence of current or previous HCV infection, what were their risk factors for exposure, and what was the frequency of use and effectiveness of barrier methods to prevent HCV infection.

Methods: Data were acquired from a cross sectional survey conducted among DCWs in 2014 at the Faculty of Dentistry, Sana'a University, in Sana'a city. A proportionate to size random sample was drawn per DCW category. A structured questionnaire was used to collect data about socio-demographic characteristics and risk factors. ELISA was used to test sera for HCV antibodies. Results: The study included 246 dentists and 263 dental assistants; the sero-prevalence of current hepatitis $\mathrm{C}$ virus infection was $1.6 \%$. Prevalence of needle stick injuries, exposure to skin and to mucous membranes were $45.6 \%, 26.5 \%$ and $25.3 \%$ respectively. Cuts were also common with $41.1 \%$ of participants reporting a cut in a period of one year preceding the survey. There was a highly significant associated with risk of $\mathrm{HCV}$ infection with needle stick injuries $(\mathrm{OR}=8.6, P=0.01$, cuts $(\mathrm{OR}=4.4, P=0.04)$, contact with blood/saliva in skin $(\mathrm{OR}=20.8, P<0.001)$. But longer duration in service was not significantly associated with risk of infection $(\mathrm{OR}=2, P$ value $=0.34)$.

Conclusion: In conclusion, the prevalence of HCV infection was high among Yemeni DCWs and eexposure to potentially infectious body fluids was high which might lead to high rate of transmit HCV to DCWs, therefore ensures a safer work environment is important in control and prevention of HCV in DCWs in Yemen.

Keywords: DCWs, HCV, Sana'a city, Yemen

Article Info: Received 5 September 2017; Revised 9 October; Accepted 1 November, Available online 15 November 2017

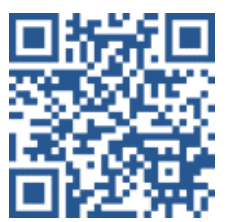

Cite this article-

Al-Kebsi MA, Othman AM, Al-Kasem MAA, Madar EM, Al-Shamahy HA, Al-Gaffari KM, Naser Daname SM, Motareb FL. Sero-prevalence of hepatitis C virus among dental clinic workers in Sana'a city- Yemen and the risk factors contributing for its infection. Universal Journal of Pharmaceutical Research 2017; 2(5): 24-29.

DOI: http://doi.org/10.22270/ujpr.v2i5.R6

Address for Correspondence:

Dr. Hassan A. Al-Shamahy, Medical Microbiology and Clinical Immunology, Faculty of Medicine and Health Sciences, Sana'a University, Yemen, Tel: : +967-1-239551, E-mail: shmahe@yemen.net.ye

\section{INTRODUCTION}

Viral hepatitis is a major public health problem, occurring endemically in all areas of the world ${ }^{1,2}$. The prevalence of the disease is influenced by numerous factors which may be able to modulate its onset ${ }^{3,4}$. The presence of HCV-RNA in saliva and mucus secretions of mouth provides a biological basis for them as possible sources of HCV infection, although it does not necessarily imply transmission, ${ }^{\mathbf{5 , 6}}$. HCV infection is one of the most important infectious occupational hazards in the dental profession ${ }^{7,8}$. A number of reports suggest that a significantly higher incidence of $\mathrm{HCV}$ among dental staff, ${ }^{2,9}$, and a higher rates of $\mathrm{HCV}$ especially oral surgeons, periodontists and endodontists $^{9,10}$. The endemicity of infection was considered low in Yemen, where prevalence of positive $\mathrm{HCV}$ antibody among general population ranged from $0.2 \%$ to $1.1 \%{ }^{11,12}$. The carriers of infection with HCV in dental practice are blood, saliva and nasopharyngeal secretions ${ }^{3-5,10}$. In intra-orally, the greatest concentration of hepatitis $\mathrm{C}$ infection is the gingival sulcus ${ }^{8,10}$. No certain case of HCV saliva transmission 
has been documented ${ }^{6,13}$. In dental management to prevent infection all patients with a history of hepatitis must be managed as they are potentially infectious, and aerosols should be minimized ${ }^{3-5}$. We present the results of a 2014 survey of dental personnel in Sana'a city, Yemen. The purposes of this survey were to evaluate what proportion of dentists and dental assistants had serological evidence of current or previous $\mathrm{HCV}$ infection, what were their risk factors for exposure, and what was the frequency of use and effectiveness of barrier methods to prevent $\mathrm{HCV}$ infection.

\section{SUBJECTS AND METHODS \\ Study area}

This cross-sectional epidemiological study was conducted among dental clinic personal care whom representative dental clinics in Sana'a city in Yemen.

\section{Study population and Sample size}

This study was carried out starting in June and ending in August 2014. A consent form was filled by each participant. The sample size for the study was calculated as follow: First, the rate of $\mathrm{HCV}$ was considered among dental clinic personals in Sana'a city, difference (worst acceptable result higher or lower the true rate) and confidence interval as $3 \%, 0.5 \%$ and $99.9 \%$ respectively. Accordingly, a sample size of at least 458 subjects was required from the population of dental clinic personals in Sana'a city [roughly $5000 \mathrm{n}$ ]. The sample was selected by a systematic random method. All dental clinics in Sana'a city were listed (321 clinics), then by the use of a simple random selection, 120 of these dental clinics were selected; finally, all persons working in the clinic were selected. About $2 \%$ of the workers refused to participate in the study.

\section{Data collection}

All participants gave oral consent, completed a questionnaire, and had blood drawn for $\mathrm{HCV}$ serological testing. The questionnaire covered demographics, professional characteristics (type, duration, quantity of practice; patient characteristics; procedures performed), protective barrier measures used during dental procedures, occupational exposures to blood and saliva, and other personal risk factors for hepatitis, such as blood transfusion, cupping, tattoo, etc.

\section{Laboratory tests}

\section{Blood sample collection}

Two ml whole blood was collected by vein puncture; then sera were separated and tested for HCV antibodies by an Enzyme-linked Immunosorbant Assay (ELISA) using a commercially available kit provided by Roche Diagnostics (Basel Switzerland).

\section{Case definitions and data analysis}

All persons with anti-HCV antibodies were considered to have had serological signs of HCV infection. To relate possible risk factors for $\mathrm{HCV}$ infection, the data were examined in a case-control study format. For $\mathrm{HCV}$, persons with evidence of infection with $\mathrm{HCV}$ were matched up with those who were $\mathrm{HCV}$ antibodies negative. Differences in categorical variables were assessed using Fisher's exact tests where appropriate. Ninety-five percent confidence intervals for odds ratios were calculated according to the method of Cornfield and $95 \%$ confidence limits for simple proportions were calculated by an exact binomial method using EPIINFO.

Table 1: Demographic and professional characteristics of the HCV survey participants, Sana'a city, Yemen, February 2014.

\begin{tabular}{|c|c|c|c|c|}
\hline \multirow[t]{2}{*}{ Characteristics } & \multicolumn{2}{|c|}{ Dentists $n=246$} & \multicolumn{2}{|c|}{$\begin{array}{c}\text { Dental assistants } \\
n=263\end{array}$} \\
\hline & Number & $\%$ & Number & $\%$ \\
\hline \multicolumn{5}{|l|}{ Gender } \\
\hline Male & 132 & 53.7 & 112 & 42.6 \\
\hline Female & 114 & 46.3 & 151 & 57.4 \\
\hline \multicolumn{5}{|l|}{ Age groups } \\
\hline$<22$ years & 37 & 15 & 68 & 25.9 \\
\hline $23-27$ years & 45 & 18.3 & 52 & 19.8 \\
\hline $28-32$ years & 52 & 21.1 & 57 & 21.7 \\
\hline $33-37$ years & 44 & 17.9 & 54 & 20.5 \\
\hline$\geq 38$ years & 68 & 27.6 & 32 & 12.2 \\
\hline \multicolumn{5}{|l|}{ Practice setting } \\
\hline Private setting & 165 & 67.1 & 175 & 66.5 \\
\hline $\begin{array}{l}\text { Governmental } \\
\text { clinic setting }\end{array}$ & 81 & 32.9 & 88 & 33.5 \\
\hline
\end{tabular}

\section{RESULTS}

A total of 509 DCWs; 246 dentists and 263 dental assistants were participated in the study. The demographic characteristics of the study sample are shown in Table 1. Among the enrolled dentists 3 $(1.2 \%) \quad(\mathrm{OR}=0.64,95 \% \quad \mathrm{CI}=0.12-3.1, \quad P=0.53) \quad$ had serological evidence of $\mathrm{HCV}$ infection while a higher non-significant rate and association among the enrolled dental assistants 5 (1.9\%), $(\mathrm{OR}=1.6,95 \% \mathrm{CI}=0.12-8.4$, $P=0.53$ ) had serological evidence of HCV infection. Among the enrolled males $3(1.2 \%)(\mathrm{OR}=0.65,95 \%$ $\mathrm{CI}=0.12-3.4, P=0.55)$ had serological evidence of $\mathrm{HCV}$ infection while higher rate and association among the enrolled females $5(1.9 \%),(\mathrm{OR}=1.54,95 \% \mathrm{CI}=0.32$ - 8.2, $P=0.55)$ had serological evidence of $\mathrm{HCV}$ infection (Table 2). To determine the possible risk factors for $\mathrm{HCV}$ acquisition, the 8 DCWs with serological evidence of HCV infection were compared to the 501 without $\mathrm{HCV}$ antibodies. There was a significance risk factors $(P=0.01)$ of needle stick injury $(\mathrm{OR}=8.6,95 \% \mathrm{CI}=1.1$ - 187$)$, cuts $(\mathrm{OR}=4.4,95 \%$ $\mathrm{CI}=0.8-31, P=0.04)$, saliva or blood exposure to skin $(\mathrm{OR}=20.8,95 \% \mathrm{CI}=2.6$ - 454), and non-significant association with salvia or blood exposure to mucus membrane $(\mathrm{OR}=3,95 \% \mathrm{CI}=0.62-14.5, P=0.1)$ with serological evidence of HCV infection (Table 3). Over $78 \%$ of the DCWs reported that they obtain in their clinics from patients a risk factor history for hepatitis B, C, and HIV mostly by written means and mostly only at the first visit (Table 4). A $74.4 \%$ of the DCWs reported consistent use of protective gloves. Only $25.3 \%$ consistent use of protective glasses and $28.3 \%$ consistent use of protective face mask. Also among our DCWs, the odds of $\mathrm{HCV}$ infection differ but not statistically significant according to the consistent use of gloves $(\mathrm{OR}=2.98,95 \% \mathrm{CI}=0.62-14.4, P=0.1)$, face masks $(\mathrm{OR}=1.2,95 \% \mathrm{CI}=0.21-8.6, P=0.83)$ or eye glasses $\quad(\mathrm{OR}=2.4, \quad 95 \% \quad \mathrm{CI}=0.3 \quad-3.4, \quad P=0.45)$, suggesting that these modalities had limited or no efficacy (Table 3 ). 
Table 2: The prevalent rate and odds ratio (risks) of contracting HCV for different occupations, gender, practice setting and duration of the wok for DCWs, Sana'a city, Yemen.

\begin{tabular}{lcccc}
\hline Factors & $\begin{array}{c}\text { Infection } \\
\mathbf{n = 8} \\
\mathbf{N}(\%)\end{array}$ & Odds ratio & CI 95\% & PV \\
& & & & \\
\hline Dentist n=246(48.3\%) & $3(1.2 \%)$ & 0.64 & $0.12-3.1$ & 0.53 \\
$\begin{array}{l}\text { Dental assistants } \mathrm{n}=263 \\
(51.7 \%)\end{array}$ & $\begin{array}{c}5(1.9 \%) \\
\text { Crude } \mathrm{n}=509\end{array}$ & 1.6 & $0.12-8.4$ & 0.53 \\
\hline Gender & $8(1.6 \%)$ & & & \\
\hline Male $\mathrm{n}=244(47.9 \%)$ & & & & \\
Female $\mathrm{n}=265(52.1 \%)$ & $3(1.2 \%)$ & 0.65 & $0.12-3.14$ & 0.55 \\
\hline Practice setting & $5(1.9 \%)$ & 1.54 & $0.32-8.2$ & 0.55 \\
\hline Private $\mathrm{n}=340(66.8 \%)$ & $6(1.8 \%)$ & 1.5 & $0.3-10.8$ & 0.61 \\
Government $\mathrm{n}=169$ & $2(1.2 \%)$ & 0.67 & $0.1-3.7$ & 0.61 \\
$(33.2 \%)$ & & & & \\
\hline Duration of the practice & & & & \\
\hline$<5$ years $\mathrm{n}=111(21.8 \%)$ & $1(0.9 \%)$ & & Reference & \\
5-10 years $\mathrm{n}=224(44 \%)$ & $3(1.3 \%)$ & 0.8 & $0.14-36$ & 0.7 \\
$>10 y e a r s \mathrm{n}=174(34.2 \%)$ & $4(2.3 \%)$ & 2.0 & $0.4-9.3$ & 0.34 \\
\hline
\end{tabular}

Table 3: Occupational possible risk factors for HCV among DCWs with previous and current HCV infection.

\begin{tabular}{lccccc}
\hline \multicolumn{1}{c}{ Possible risk factors } & $\begin{array}{c}\text { Exposure } \\
\mathbf{N}(\mathbf{\%})\end{array}$ & $\begin{array}{c}\text { Infection } \mathbf{n = 8} \\
\mathbf{N}(\boldsymbol{\%})\end{array}$ & $\begin{array}{c}\text { Odds } \\
\text { ratio }\end{array}$ & CI 95\% & PV \\
\hline Needle stick injuries & $232(45.6)$ & $7(3 \%)$ & 8.6 & $1.1-187$ & 0.01 \\
Cuts & $209(41.1)$ & $6(2.9 \%)$ & 4.4 & $0.8-31$ & 0.04 \\
\hline Contact with blood/saliva & & & & & \\
\hline On skin & $133(26.5)$ & $7(5.3 \%)$ & 20.8 & $2.6-454$ & $<0.001$ \\
On mucus membrane & $129(25.3)$ & $4(3.1 \%)$ & 3 & $0.62-14.5$ & 0.1 \\
\hline Consisting using & & & & & \\
\hline Gloves & & & 0.34 & $0.1-1.6$ & \\
Yes & $379(74.4)$ & $4(1.1 \%)$ & & & 0.1 \\
No & $130(25.6)$ & $4(3.1 \%)$ & & \\
& & & 2.98 & $0.62-14.4$ & \\
\hline Glasses & $129(25.3)$ & $1(0.8 \%)$ & 0.42 & $0.0 .02-3.4$ & \\
Yes & $380(74.7)$ & $7(1.8 \%)$ & 2.4 & $0.3-52$ & 0.45 \\
No & & & & \\
\hline Face mask & $144(28.3)$ & $2(1.4)$ & 0.84 & $0.17-4$ & 0.83 \\
Yes & $365(71.7)$ & $6(1.64)$ & 1.2 & $0.21-8.6$ & \\
No & & & & \\
\hline
\end{tabular}

\section{DISCUSSION}

During recent years, in Yemen, Health care authorities as well as patients and family patients are increasingly concerned about possible professional to-patients and vice-versa transmission of hepatitis B virus (HBV), hepatitis $\mathrm{C}$ virus (HCV) and other blood born viruses. Such general anxiety is well reflected in conducted this study, in our opinion this emerging issue should be more extensively discussed in medical community in Yemen. Until now, no reports or limited studies conducted about prevalence of $\mathrm{HCV}$ among dental clinic worker (DCWs) and associated factors which might be increased the possible professional to-patients and vice- versa transmission of hepatitis $C$ virus.

Current results suggest that occupational transmission of $\mathrm{HCV}$ in dental settings occurs sometimes, and frequently. The finding that more than $1.6 \%$ of Sana'a city DCWs had HCV antibodies was opposing with prevalence of zero $\%$ found among general dentists in $\mathrm{Japa}^{14}$ but roughly similar to that reported in other Asian and North America in which the prevalence rate of $\mathrm{HCV}$ among general dentists was about $1.8 \%{ }^{15}$. On the other hand, our rate $(1.6 \%)$ is lower than that reported by Hussain et al., in Iraq in which the prevalence rate of $\mathrm{HCV}$ among general dentists was $9.3 \%$. Also our rate is roughly similar to that reported among blood donors in Yemen in which $1.1 \%$ of the donors in Hajjah Governorate were infected with hepatitis $\mathrm{C}^{11}$. However our prevalence rate $(1.6 \%)$ among DCWs is higher than that reported by AlNabahi et al., in which the prevalence of hepatitis $\mathrm{C}$ in 2014 in Sana'a city and Aden city among general population were $0.2 \%$ and $0.6 \%$ respectively ${ }^{12}$. Also the prevalence of hepatitis $\mathrm{C}$ among our individuals is higher than that reported from the neighboring countries including in which it is ranged from $0.5 \%$ to $1.0 \%$ among general populations ${ }^{16}$. Such small differences in prevalence rates may be explained by the fact that DCWs are risk group of $\mathrm{HCV}^{17}$.

The specific dentist prevalence rate was $1.2 \%$ slightly lower than dental assistant prevalence rate 1.9\% (Table 2 ). This result was similar to that reported in Taiwan and other developed countries where a higher prevalence among dental assistants was found ${ }^{2,18}$. With regard to this slightly difference between percentages of infection in dentists and dental assistants, this is may be attributed to several possible reasons. One of the most common reasons is the different level of 
unprotected exposure to patients' body fluids and needle stick injuries in both groups. Other reasons of being infected with hepatitis virus may be related to family history and dental procedures ${ }^{3}$. The specific male prevalence rate was $1.2 \%$ slightly lower than female prevalence rate $1.9 \%$ (Table 2 ). The prevalence rate in current study was similar to the sex distribution of $\mathrm{HCV}$ infection in African and American countries where equal distribution is the features in all reports of general population and risk groups ${ }^{19,20}$.

Table 4: The methods of taking patients history for infection (HBV, HCV, and HIV) by DCWs for the dental clinic visitors.

\begin{tabular}{|c|c|c|}
\hline Methods & Nun & $\%$ \\
\hline \multicolumn{3}{|c|}{$\begin{array}{l}\text { Patients history type for infection (HBV, } \\
\mathrm{HCV}, \mathrm{HIV} \text { etc) }\end{array}$} \\
\hline Written only & 146 & 28.7 \\
\hline Oral only & 34 & 6.7 \\
\hline Written and oral & 83 & 16.3 \\
\hline None & 254 & 49.9 \\
\hline \multicolumn{3}{|c|}{ Patients history frequency } \\
\hline At first visit & 212 & 41.6 \\
\hline At certain intervals & 35 & 6.9 \\
\hline Each visit & 8 & 1.6 \\
\hline
\end{tabular}

When we considered, the practice setting, there was slightly higher rate of $\mathrm{HCV}$ among private DCWs (1.9\%), comparing with $1.2 \%$ for government DCWs (Table 2). This result was different to that reported in Taiwan and Germen where similar prevalence among DCWs was found ${ }^{18,21}$. This continuing high risk in both the practice settings could be in part due to inconsistent use of or ineffectiveness of recommended barrier prevention measures to prevent transmission of bloodborne infections in, private and government practice settings. The results of this study indicated that the prevalence of HCV among Yemeni DCWs was none significantly affected by the duration of the practice (long duration independent) as shown in Table 2. Some studies that covered wider range of duration in several groups indicated that the prevalence of $\mathrm{HCV}$ is long duration dependent, in which the rate increases with increasing duration of practices ${ }^{18,20-22}$. An exposure can be defined as a percutaneous injury (e.g., needle stick or cut with a sharp object) or contact of mucous membrane or no intact skin (e.g., exposed skin that is chapped, abraded, or with dermatitis) that occurs during the course of persons employment, with blood, saliva, tissue, or other body fluids that are potentially infectious. Because accidents with needles are one of the most common types of injury in the health care setting, injuries from needles are often called needle stick injuries ${ }^{23}$. In current study $45.6 \%$ of our HCWs were exposed to needle stick injuries, and significant risk for $\mathrm{HCV}$ infection after a needle stick was 8.9 (OR) $(P=0.01)$, and the prevalence of HCV in dental staff exposed to this was 3\% (Table 3). Our result was in the same range that reported by Tokars and others in which the prevalence of $\mathrm{HCV}$ in dental staff exposed to needle stick injuries has varied from 0 to $6.2 \%^{5,24,25}$. Also Ppolito and others stated that the risk following a needle stick injuries in DCWs is known and is believed to be greater if the source patient is positive for $\mathrm{HCV}$
RNA, with no transmission occurring from HCV RNA negative sources ${ }^{26,27}$. In current study $41.1 \%$ of our HCWs were exposed to cuts, and significant risk for HCV infection after a cut was $4.4(\mathrm{OR})(P=0.04)$, and the prevalence of $\mathrm{HCV}$ in dental staff exposed to cuts was $2.9 \%$ (Table 3 ). Our rate among DCWs exposed to cuts $(2.9 \%)$ was in the same range that reported by $\mathrm{CDC}$ in which the prevalence of HCV in dental staff exposed to cuts has varied from 0 to $6.2 \%^{5,24,25}$. Resemblance to findings in New York $\mathrm{City}^{7}$, where cut injuries were the most frequently recorded exposures among dental workers; the use of manual instruments for tooth cleaning appears to be associated with the highest rate of occupational injury in current study. This is somewhat similar to findings in the UK, which noted that the greatest percentage of exposures amongst dental workers occurred during tooth cleaning $^{28}$. Manual cleaning of teeth and root surfaces requires dexterity and good techniques. Current study suggests that there may an indication for more training of the dental care workers especially in work practice controls. Such controls might include restricting the use of the fingers for tissue retraction and minimizing the potential uncontrolled movements of scalars and similar instruments. No prophylactic measures involving drugs or immunoglobulins are at present available so first aid management is very important. It is essential a baseline sample is taken at the time of injury. No effective vaccination has been developed against $\mathrm{HCV}^{5}$.

In current study $26.5 \%$ of our HCWs were exposed to blood or saliva on skin. The prevalence rate to HCV to DCWs exposed to blood or saliva on skin was $5.3 \%$ (Table 3). The risk following a blood splash is unknown but is believed to be greater if the source patient is positive for HCV RNA, with no transmission occurring from HCV RNA negative sources. Among the Sana'a DCWs, the odds of HCV infection differ but not statistically significant according to the consistent use of gloves, face masks or eye glasses, (Table 3) suggesting that these modalities had limited or no efficacy. Unfortunately, there are few other comparison data about the efficacy of barrier prevention measures. Studies conducted during the 1990 s and 80 s showed no relationship between the use of gloves, face masks, or eye protection and previous HBV infection ${ }^{29,30}$. However, in two studies, so few dentists used face masks that the power to detect a protective effect was low ${ }^{7,30}$. The conclusion that face masks may have reduced the risk of $\mathrm{HCV}$ infection must be interpreted with some caution as the small number of $\mathrm{HCV}$ infected dentists precluded a multivariate analysis to examine potential confounding factors. In addition, this study only had an approximately $50 \%$ power to detect a fourfold reduction in the odds of previous infection by gloves or eye glasses. Nevertheless, the fact that the point estimates of the odds ratios were $1 \pm 1$ would suggest that no significant effect would have been found even with a much larger sample size. Also, DCWs use of personal protective equipment in this study, which is a critical component of standard precautions, was found to be similar to Ammon et al., and Kim et al., previous studies ${ }^{21,31}$ which noted that 
the use of protective eyewear was inadequate similar to current result for example only 25.3 percent of the DCWs in this study were wearing protective eye shields. Although some DCWs wore prescription glasses, prescription glasses alone are not acceptable to adequately protect the eyes. Protective eyewear should have solid side shields or alternatively a face shield $^{22,32}$. This finding, however, is not peculiar to Sweden, as the study in the UK also noted that 60 percent of the students were not wearing protective eyewear when they experienced an exposure incident $^{30,33}$. While the risk of infection is less with mucosal splash than via percutaneous injuries, this may be an important route of exposure in this population, considering the fact that saliva and blood splashes were the next most commonly cited exposures after puncture wounds. DCWs should receive instructions to help them understand the risks associated with treating patients without protective eyewear; hopefully, comprehension of the risks will improve compliance with the use of protective eyewear.

\section{CONCLUSION}

A combination of standard precautions, engineering, work practice, and administrative controls are the best means to minimize occupational exposures amongst all oral health care workers. It is the responsibility of training institutions to ensure the safety of the DCWs by requiring mandatory $\mathrm{HBV}$ vaccination prior to exposure and adequate training in work safety. It is important that there are written policies and procedures to facilitate prompt reporting and management of all occupational exposures; this information should be made easily accessible to all workers. Adequate monitoring mandates the reporting of all occupational exposures and is a means of quality control in health care delivery. We would like to recommend, therefore, that processes for monitoring occupational exposures be made functional in all Yemen dental clinics and schools to promote safety, quality, and value in the oral health care services provided.

\section{AUTHOR'S CONTRIBUTION}

The manuscript was carried out, written, and approved in collaboration with all authors.

\section{ACKNOWLEDGEMENTS}

The authors extend their thanks and appreciation to the Sana'a University, Yemen to provide necessary facilities for this work.

\section{CONFLICT OF INTERESTS}

No conflicts of interest are associated with this work.

\section{REFERENCES}

1. Foster K. Hepatitis C infections may come from routine dentistry. The Scotsman 2001; 25: 47-51.

2. Leao JC, Teo CG, Porter SR. HCV infection: aspects of epidemiology and transmission relevant to oral health care workers. Int J Oral Maxillofac Surg 2006; 35(4): 295-300. https://doi.org/10.5272/jimab.14-2-2008.38

3. Cleveland JL, Gooch BF, Shearer BG. Risk and prevention of hepatitis $\mathrm{C}$ virus infection: implications for dentistry. J Am Dent Assoc 1999; 130: 641-647.
4. Kerr SP, Blank LW. Percutaneous injuries among dental health care workers. Gen Dent. 1999; 47: 146-151.

5. Global Dental Safety Organization 2016. Focus Issue: Hepatitis $\mathrm{C}$ virus and dentistry.html

6. Arrieta JJ, Rodríguez-Iñigo E, Ortiz-Movilla N, Bartolomé J, Pardo M, Manzarbeitia F, et al. Detection of hepatitis C virus RNA in salivary glands. Am J Pathol 2001; 158(1): 259-64.https://doi.org/10.1016/S0002-9440(10)63964-8

7. Klein RS, Freeman, Taylor RE, Stevens CE. Occupational risk for hepatitis $\mathrm{C}$ virus infection among New York City dentists. Lancet. 1991; 338: 1539-42. https://doi.org/10.1155/2019/9482607

8. Suzuki T, Omata K, Satoh T, Miyasaka T, Arai C, Maeda $\mathrm{M}$, et al. Quantitative detection of hepatitis $\mathrm{C}$ virus (HCV) RNA in saliva and gingival crevicular fluid of $\mathrm{HCV}-$ infected patients. J Clin Microbiol 2005; 43(9): 4413-7. https://doi.org/10.1128/JCM.43.9.4413-4417.2005

9. Hussain Abbass Ibrahim, Anizy Hamid Hammad. Prevalence of viral hepatitis $\mathrm{B}$ and $\mathrm{C}$ among dentistry professionals in Anbar province. J Al-anbar University for pure science.2008; 2:1-7.

10. Farghaly AG, Mansour GA, Mahdy, NH, Yousri A. Hepatitis $\mathrm{B}$ and $\mathrm{C}$ virus infections among patients with gingivitis and adult periodontitis: seroprevalence and public health importance. Egypt Public Health Assoc 1998; 73(5-6): 707-35. https://doi.org/10.1016/j.jiph.2012.12.003

11. Haidar NA. Prevalence of hepatitis B and hepatitis C in blood donors and high risk groups in Hajjah, Yemen Republic. Saudi Med J 2002; 23(9):10904.

12. Al- Nabehi BAH, Al- Shamahy H, Saeed WSE, Musa AM, El Hassan A.M. and Khalil EAG. Sero-molecular epidemiology and risk factors of viral hepatitis in Urban Yemen. Int J Virol 2015; 11: 133-138. https://doi.org/10.3923/ijv.2015.133.138

13. Toussirot E, Le Huédé G, Mougin C, Balblanc JC, Bettinger D, Wendling DJ. Presence of hepatitis C virus RNA in the salivary glands of patients with Sjögren's syndrome and hepatitis $\mathrm{C}$ virus infection. Rheumatol 2002; 29 (11): 2382-5.PMID: 12415596

14. Nagao Y, Matsuoka H, Kawaguchi T, Ide T, Sata M. HBV and HCV infection in Japanese dental care workers. Int $\mathrm{J}$ Mol Med 2008; 21(6): 791-9. https://doi.org/10.3892/ijmm.21.6.791

15. Stevens AB, Coyle PV. Hepatitis C virus: an important occupational hazard? Occup Med (Lond). 2000; 50(6):377-82.https://doi.org/10.1186/s12912-020-00422-0

16. Al-Tamimi W, Al Traif I, El Shaikh M, Al Kashan A, Qasem L, Sohaibani M: Prevalence of HBsAg and antiHCV in Saudi blood donors. Ann Saudi Med 1998; 18: 60-2. https://doi.org/10.5144/0256-4947.1998.60

17. Albeldawi M, Ruiz-Rodriguez E, Carey WD. Hepatitis C virus: prevention, screening, and interpretation of assays. Cleve Clin J Med 2010; 77: 616-626.

18. Kwo MY, Hahn LJ, Hong CY, Kao JH, Chen DS. Low prevalence of hepatitis $\mathrm{C}$ virus among dentists in Taiwan. J Med Virol 1993; 40: 10-3. https://doi.org/10.1002/jmv.1890400104

19. Mehta SH, Brancati FL, Sulkowski MS, et al. Prevalence of type 2 diabetes mellitus among persons with hepatitis $\mathrm{C}$ virus infection in the United States. Ann Intern Med 2000; 133: 592-9. https://doi.org/10.7326/0003-4819-133-8200010170-00009

20. Mitchell AE, Colvin HM, Palmer Beasley R. Institute of Medicine recommendations for the prevention and control of hepatitis B and C. Hepatology 2010; 51: 729-733. https://doi.org/10.1002/hep.23561

21. Ammon A, Reichart RA, Pauli G and Petersen LR. Hepatitis B and C among Berlin dental personnel: incidence, risk factors, and effectiveness of barrier prevention measures. Epidemiol Infect 2000; 125:407413.https://doi.org/10.1017/s0950268899004537 
22. Thomas DL, Gruninger SE, Siew C, Joy ED, Quinn TC. Occupational risk of hepatitis $\mathrm{C}$ infections among general dentists and oral surgeons in North America. Am J Med 1996; 100: 41-5. https://doi.org/10.1016/S00029343(96)90009-1

23. Gupta N, Tak J. Needlestick injuries in dentistry. Kathmandu Univ Med J 2011; 35(3):208-12.

24. CDC. Recommendations for follow-up of HCW after occupational exposure to hepatitis C virus. MMWR Morb Mortal Wkly Rpt 1997; 46: 603-606.

25. Tokars JI, Marcus R, Culver DH et al. Surveillance of HIV infection and zidovudine use among health care workers after occupational exposure to HIV infected blood: the CDC Cooperative Needle stick Surveillance Group. Ann Intern Med 1993; 118: 913-9.

https://doi.org/10.7326/0003-4819-118-12-19930615000001

26. Ppolito G, Puro V, De Carli G and the Italian Study Group on Occupational Risk of HIV infection. The risk of occupational human immunodeficiency virus infection in health care workers. Archs Intern Med 1993; 153:1451-8. https://doi.org/10.1016/S0002-9343(97)89441-7

27. Shepard CW, Finelli L, Alter MJ. Global epidemiology of hepatitis $C$ virus infection. Lancet Infect Dis 2005; 5:558567.https://doi.org/10.1016/S1473-3099(05)70216-4
28. Nash KD. How infection control procedures are affecting dental practice today. J Am Dental Assoc 1992; 123: 6773.https://doi.org/10.14219/jada.archive.1992.0076

29. Reingold AL, Kane MA, Hightower AW. Failure of gloves and other protective devices to prevent transmission of hepatitis B virus to oral surgeons. JAMA 1988; 259: 2558-60. PMID: 3357229

30. Hellegran K. Use of gloves among dentists in Sweden. a 3-year follow-up study. Swed Dent J 1994; 18: 9-14. PMID: 8052954

31. Kim WR, Ward JW, Cheever LW, Dan C, Dee L, Zola J. Transforming the current infrastructure for combating HBV and HCV infections. J Fam Pract 2010; 59:S65-S70. PMID: 20398593

32. Peters MG, Weinbaum C, Tan L, Baine WB, Dienstag JL, Liang TJ, et al. Recommendations for prevention, screening, and diagnosis of HBV and HCV infections. J Fam Pract 2010; 59: S29-S35.PMID: 20398588

33. Scully C, Griffiths M, Levers H, Blake C, Chartres L. The control of cross-infection in UK clinical dentistry in the 1990s: immunization against hepatitis B. Br Dent J 1993; 174: 29-31.https://doi.org/10.1038/sj.bdj.4808063 